\title{
Sexual ratio and floral biology of the dioecious Neea theifera Oerst. (Nyctaginaceae) in a cerrado rupestre of central Brazil
}

Felipe Wanderley Amorim ${ }^{1,2,3}$, Clesnan Mendes-Rodrigues ${ }^{1}$, Pietro Kiyoshi Maruyama ${ }^{1}$ and Paulo Eugênio Oliveira ${ }^{1}$

Recebido em 10/03/2011. Aceito em 9/09/2011

\begin{abstract}
RESUMO
(Razão sexual e biologia floral de Neea theifera Oerst. (Nyctaginaceae), uma espécie dióica na vegetação de um cerrado rupestre no Brasil Central). Dioicia é caracterizada pela separação completa das funções sexuais, na qual plantas apresentam indivíduos masculinos e femininos. Este sistema evoluiu muitas vezes entre as Angiospermas e está amplamente distribuído entre as distintas famílias. É visto como uma estratégia reprodutiva para reduzir a endogamia e otimizar a alocação diferencial de recursos entre as funções sexuais masculinas e femininas. Neea theifera é uma espécie comum no Cerrado, área de Savana Neotropical no Brasil, mas informações acerca de sua biologia reprodutiva são incompletas. Para investigar se as condições ambientais afetam espécies dióicas, foi estudada sua biologia floral, a razão sexual e distribuição espacial dos morfos ao longo de um gradiente de solo-altitude. A razão sexual da população não diferiu da razão esperada de 1:1. Porém, a abundância de flores estaminadas na população foi significativamente maior. Os indivíduos femininos foram maiores que os masculinos e o tamanho das plantas correlacionou-se negativamente com a altitude, apesar de não diferirem entre os morfos sexuais. A população não apresentou segregação espacial dos morfos sexuais e os indivíduos masculinos apresentam maturação sexual precoce em relação aos femininos. Flores estaminadas foram maiores que as pistiladas, além de apresentarem alta viabilidade polínica. Abelhas Meliponini, pequenas moscas e tripes foram os potenciais polinizadores, entretanto o sucesso de polinização foi muito baixo. A dioicia em $N$. theifera corrobora muitas características gerais desta estratégia reprodutiva, como hábito lenhoso, flores inconspícuas, polinização por pequenos insetos generalistas e alocação diferencial de recursos entre indivíduos masculinos e femininos. Porém, a reprodução nesta espécie é aparentemente afetada por limitação de polinizadores. Os resultados mostram que o gradiente de solo-altitude influencia o padrão de crescimento da espécie e pode ter um importante papel na biologia reprodutiva da planta, mas não afeta diretamente a dioicia.
\end{abstract}

Palavras-chave: dioicia, estrutura sexual, distribuição espacial, Savana Neotropical, polinização

\begin{abstract}
(Sexual ratio and floral biology of the dioecious Neea theifera Oerst. (Nyctaginaceae) in a cerrado rupestre of central Brazil). Dioecy is characterized by a complete separation of sexual functions on male and female plants. It has evolved many times in flowering plants and is widespread among distinct Angiosperm families. It is viewed as a reproductive strategy to reduce endogamy, and to promote optimal resource allocation between male and female sexual functions. Neea theifera is a common species in Cerrado, neotropical savannas in Brazil, but information regarding its reproductive biology is still incomplete. In order to investigate how environmental conditions possibly affect this dioecious species, we studied its floral biology, sex ratio and spatial distribution of sexual morphs along a soil-altitudinal gradient. The sex ratio did not significantly deviate from the expected 1:1 ratio. However, flower abundance in the population was significantly biased towards staminate flowers. Female individuals were larger than male individuals and plant size was negatively correlated with altitude, but did not differ between sexual morphs. The population did not show spatial segregation of sexes and male individuals were sexually mature earlier than female ones. Staminate flowers were larger than pistillate flowers and presented high pollen viability. Meliponini bees, small flies and thrips were potential pollinators, but pollination success was very low. Dioecy in N. theifera corroborates many general features of this reproductive strategy, such as woody habit, inconspicuous flowers, pollination by small generalist insects and differential resource allocation between male and female plants. However, reproduction in this species seems to be impaired by pollinator limitation. The results showed that the soil-altitude gradient influenced the growth pattern of the species and may play an important role in its reproductive biology but did not affect dioecy directly.
\end{abstract}

Key words: altitudinal gradient, dioecy, neotropical savanna, sexual structure, pollination

\footnotetext{
Universidade Federal de Uberlândia, Instituto de Biologia, Uberlândia, MG, Brazil

2 Universidade Estadual de Campinas, Departamento de Biologia Vegetal, Campinas, SP, Brazil

3 Author for correspondence: amorimfelipe@yahoo.com.br
} 


\section{Introduction}

Dioecy is a widespread reproduction strategy in Angiosperms characterized by the complete separation of the sexual function of male (producers of staminate flowers) and female (producers of pistillate flowers) individuals (Bawa 1980; Renner \& Ricklefs 1995; Freeman et al. 1997). It evolved independently many times, which was possibly caused by different evolutionary pressures (Mitchell \& Diggle 2005). Plant-pollinator interaction, exogamic maximization and disruptive evolutionary processes, which lead to sexual specialization and differential resource allocation between male and female functions, are presumed to drive the evolution of dioecy in flowering plants (Bawa 1980; Thomson \& Barret 1981; Freeman et al. 1997). Although generalizations must be considered with caution, this reproductive strategy seems to be most associated with tropical species, shrubs and trees, massive production of small and inconspicuous pale-colored flowers, pollination by small generalist insects and production of zoochorous fruits (Bawa 1980; Renner \& Feil 1993; Renner \& Ricklefs 1995; Vamosi et al. 2003; Vamosi \& Vamosi 2004).

Besides differences in the sexual structures per se (i.e., flowers), dioecious plants often show differences between genders in other features, such as floral display (flower quantity), floral rewards and demography (Freeman et al. 1997; Lenza \& Oliveira 2005; Amorim \& Oliveira 2006). Individuals of different sexes in dioecious plants present distinct patterns in resource allocation and consequently the resource requirements are not equal (Freeman et al. 1997). In this sense the biology and population structures of some dioecious species may be strongly influenced by environmental factors, such as climate, soil and altitude (Freeman et al. 1997). These factors can influence the spatial distribution of sexual morphs as much as growing pattern, sex ratio and even pollination ecology of dioecious populations (Freeman et al. 1997; Marques et al. 2002; Ortiz et al. 2002).

The worldwide occurrence of dioecy in flowering plants is about 6\% (Renner \& Ricklefs 1995) but some neotropical plant communities present an oddly high incidence of dioecious plants as recorded in studies from the Cerrado (Oliveira 1996) and Atlantic Forest (Matallana et al. 2005) in Brazil, lowland rain forest in Costa Rica (Bawa et al. 1985) and cloud forest in the Venezuelan Andes (Sobrevilla \& Arroyo 1982). The incidence of dioecious species could reach ca. 30\% in Cerrado (Oliveira 1996), which emphasizes the importance of sexual reproduction mediated by biotic vectors in this biome (Oliveira 1996; Oliveira \& Gibbs 2000). Among the woody Cerrado flora, Nyctaginaceae are represented basically by two genera, Guapira Lund. and Neea Oerst., which are typically dioecious. Neea theifera is a shrub to tree species presenting small and inconspicuous flowers occurring at cerrado sensu stricto (savanna like vegetation) and cerrado rupestre (cerrado on rocky outcrops) in this biome (Oliveira 1996; Silva Jr. 2005).
Detailed information regarding the biology of $N$. theifera is unavailable even though this species is frequently mentioned in Cerrado plant community studies (e.g., Batalha \& Mantovani 2000; Oliveira \& Gibbs 2000; Borges \& Shepherd 2005; Martins \& Batalha 2006). Considering that this species is relatively abundant and frequent in Cerrado areas, and in order to investigate how environmental conditions possibly affect the biology of a dioecious species, we studied aspects of its floral biology and population ecology based on the determination of sex ratio and spatial distribution of sexual morphs along a soil-altitudinal gradient.

\section{Material and methods}

\section{Study area}

Fieldwork was carried out at Parque Estadual da Serra de Caldas Novas - PESCAN (17²46’ S - 48³9’ W), in Goiás State, during October 2006. The PESCAN comprises an area of 12,500 ha, which is mostly on an elevated plateau with a 1,043 m mean elevation a.s.l. The climate in the area is markedly seasonal and of the Aw type (according to Köppen 1948), with a dry and cold winter and humid and hot summer, and presents an annual mean temperature and precipitation of $22{ }^{\circ} \mathrm{C}$ and $1,500 \mathrm{~mm}$, respectively (Santos 2003). The dominant plant physiognomy is cerrado sensu stricto, with patches of closed woodland vegetation known as as cerradão (sensu Ribeiro \& Walter 1998). Other plant physiognomies of PESCAN are associated with a particular topography, such as valleys where forest formations occur and hillside areas with cerrado rupestre. The later is defined as subtypes of shrub and arboreal formations with litholic or rocky soils (sensu Ribeiro \& Walter 1998). The crown cover ranges from 5 to $20 \%$ occurring among rock outcrops on small patches formed by the decomposition of sandstone and quartzite, which is generally nutrient poor, acidic and has low organic matter content (Ribeiro \& Walter 1998; Mendes-Rodrigues et al. 2010). In PESCAN, Neea theifera is predominantly distributed on hillsides within cerrado rupestre where it is relatively more abundant than in cerrado sensu stricto (Silva et al. 2002; Lima et al. 2010; Lopes et al. 2010). In cerrado rupestre (at PESCAN) the soil shows decreasing fertility and a progressive increase of acidity, aluminum content and saturation as the elevation increases (Mendes-Rodrigues et al. 2010).

\section{Population study}

The population sex ratio (SR) was determined by characterizing the individual floral morph type directly in the field along an altitudinal gradient of $225 \mathrm{~m}$, which started at 745 $\mathrm{m}$ and went to $970 \mathrm{~m}$ a.s.l. This was done by searching for plant individuals near the main access road to the plateau, which covers an area of approximately 5.0 ha. To verify a possible relationship between the altitudinal gradient and the sex ratio, we subdivided the gradient it in three classes 
of $75 \mathrm{~m}$ and calculated the sex ratio within each class. The lower gradient ranged from 745 to $820 \mathrm{~m}$ a.s.l., the medium from 821 to $895 \mathrm{~m}$ a.s.l. and the higher gradient from 896 to $970 \mathrm{~m}$ a.s.l. The sex ratio was calculated as the division of the number of male individuals by the female individuals. Besides the number of individuals itself, the sex ratio in dioecious plants depends operationally on the proportion between staminate and pistillate flowers in the population (Opler \& Bawa 1978; Freeman et al. 1997). This relationship has consequences on the fitness of unisexual flowers, and may determine the sexual allocation pattern in the population (see López \& Dominguez 2003). The operational sex ratio (OSR, sensu Emlen \& Oring 1977) was determined by quantifying the number of flowers per inflorescence $\left(R_{1}\right)$ and the number of inflorescences per individual $\left(R_{2}\right)$ and calculated as $\mathrm{OSR}=\mathrm{R}_{1} \mathrm{R}_{2} \mathrm{SR}$.

The number of flowers per inflorescence was quantified by sampling 21 inflorescences for each gender distributed in eight individuals per sexual morph. For each inflorescence, we counted the number of buds, flowers and flower scars as an estimation of total number of flowers produced. To estimate the number of inflorescences per individual we choose three individuals of similar size for each sex and counted the number. To evaluate the relationship between the altitude and plant growth pattern we measured the trunk circumference at $30 \mathrm{~cm}$ from the ground, the plant height and the altitude a.s.l. of its location (with GPS; Global Position System) for all flowering individuals. With the measurement of the trunk circumferences (c), we calculated the total basal area $\left(\mathrm{BA}_{\mathrm{t}}\right)$. For individuals with ramification below the $30 \mathrm{~cm}$ from the ground, we measured each branch separately and summed the values.

\section{Floral biology}

We carried out visual observations from $08 \mathrm{~h} 00$ to $18 \mathrm{~h} 00$ to record visitors at flowers. At least fifty individuals per sex were randomly observed within this period totaling 10 hours of observation. A complementary observation session was made from $19 \mathrm{~h} 00$ to $20 \mathrm{~h} 30$ to record possible nocturnal visitors. Ten inflorescences of 10 different individuals for each sex were collected to establish possible pollinators. Each inflorescence was maintained after collection inside a death chamber containing Ethyl-acetate which incited flower visitors out of the flower chamber. Visitors were collected and fixed in a $70 \%$ alcohol solution for later identification.

Pollination service efficiency was estimated by analyzing flowers using a fluorescent microscopy, in order to observe pollen tube growth (Martin 1959). We collected 50 pistils of naturally exposed pistillate flowers distributed throughout the eight plants. Flowers were fixed in a solution of 50\% formalin, acetic acid and ethylic alcohol (50\% FAA) before treatment. Male fertility was estimated by a pollen viability analysis. Five staminate flowers per individual were collected, from which 300 pollen grains per flower were analyzed ( $\mathrm{n}=5$ individuals, total of 7500 pollen grains). Anthers were washed with distillated water above a glass slide and pollen grains were stained with acetic carmine for observation under a light microscope. Unstained or abnormally shaped pollen grains were considered non-viable.

Morphometric data was obtained using a caliper (error, $0.01 \mathrm{~mm}$ ) for 100 flowers of each sex distributed throughout ten individuals per sexual morph (10 flowers per individual). Data recorded were: corolla length $(\mathrm{cl})$ and corolla diameter (cd). To compare the flowers of each sex using these parameters at the same time we calculated the cylindrical volume of the flower $(\mathrm{FV})$ as: $\mathrm{FV}=\pi(\mathrm{cd} / 2)^{2} \mathrm{cl}$.

\section{Statistic analyses}

Differences between male and female plants were tested for plant height, basal area, flower morphology, number of flowers per inflorescence and inflorescence per plant with the Mann-Whitney $(U)$ test or Student's $t$-test according to data distribution (Zar 1999). Possible deviation from the expected 1:1 sex ratio was tested with the Chi-square test with Yates correction for the entire population and within each altitudinal gradient (Zar 1999). To test whether a gender spatial segregation (i.e., grouped distribution of sexes) occurs in the population we performed the Run test (Zar 1999 according to Oliveira 1996; Amorim \& Oliveira 2006). Differential sexual maturation and mortality (plant performance) between sex morphs were estimated using values of plant basal area as a relative parameter to measure plant age (sensu Opler \& Bawa 1978). The differences of the accumulated frequency of smaller and larger classes of basal area were evaluated by Kolmogorov-Smirnov $(D)$ test (Sokal \& Rohf 1981), according to Opler \& Bawa (1978). Soil-altitudinal gradient influence on plant performance was evaluated by Spearman's rank correlation test between altitude and plant height and also basal area.

\section{Results}

\section{Population study}

We recorded the sex of 323 individuals, 154 in the lower (745 to $820 \mathrm{~m}$ a.s.l.), 135 in the medium ( 821 to $895 \mathrm{~m}$ a.s.l.) and 34 at the higher altitude (896 to $970 \mathrm{~m}$ a.s.l.). Although the SR for the entire population was slightly biased toward male individuals, they did not significantly deviate from the expected $1: 1$ ratio $\left(\mathrm{SR}=1.11 ; 170\right.$ males and 153 females; $\chi^{2}=$ $0.793 ; \mathrm{df}=1 ; P=0.373)$. There were no significant differences of sex ratio for each class of altitude. In the lower class interval the SR was 1.37 ( 89 males and 65 females; $\chi^{2}=3.435 ; \mathrm{df}=1 ; P$ $=0.063$ ), in the medium altitude it was 0.85 (62 males and 73 females; $\left.\chi^{2}=0.741 ; \mathrm{df}=1 ; P=0.349\right)$ and in the higher class it was 1.27 (19 males and 15 females; $\chi^{2}=0.265 ; \mathrm{df}=1 ; P=$ 0.607). In contrast, the OSR indicates a production of almost four times more staminate flowers than pistillate flowers for the entire population (OSR $=3.92)$, showing significant bias toward staminate flowers (3.800 staminate flowers and 970 
pistillate flowers; $\left.\chi^{2}=919.28 ; \mathrm{df}=1 ; P<0.0001\right)$. Concerning individual size, female individuals were taller than male individuals (Tab. 1). There was no spatial aggregation of sexual morphs (run test: $\mathrm{n}=323$; number of Runs $=169 ; t=$ $1.71 ; P>0.05$ ), and we recorded a higher frequency of male plants in the smaller classes of basal area, which suggests an earlier sexual maturation in male individuals than in females (Kolmogorov-Smirnov $(D)=0.1654 ; P<0.05)$ (Fig. 1). The plants were smaller (height and basal area) at higher altitudes for both sexes; however, correlation indices did not indicate a strong relationship (Tab. 1).

Table 1. Variation in plant size (height and basal area) between staminate (male) and pistillate (female) individuals of Neea theifera and the values of Spearman's rank correlation (rs) in relation to altitude at PESCAN, Caldas Novas, GO, Brazil. Different letters at the same column indicate statistically significant differences between sexes $(P<0.01)$ using Mann-Whitney $(U)$ test.

\begin{tabular}{lcccc}
\hline & \multicolumn{2}{c}{ Height $(\mathrm{m})$} & \multicolumn{2}{c}{ Basal area $\left(\mathrm{cm}^{2}\right)$} \\
\cline { 2 - 5 } & Mean $\pm \mathrm{SD}$ & rs & Mean $\pm \mathrm{SD}$ & rs \\
\hline Male & $1.90 \pm 0.72 \mathrm{a}$ & $-0.225^{* *}$ & $56.99 \pm 62.17 \mathrm{a}$ & $-0.220^{* *}$ \\
Female & $2.16 \pm 0.67 \mathrm{~b}$ & $-0.163^{*}$ & $69.18 \pm 60.05 \mathrm{~b}$ & $-0.164^{*}$ \\
$U$ & 10570.5 & & 10558.5 & \\
\hline
\end{tabular}

${ }^{*} P<0.05{ }^{* *} P<0.01$

\section{Floral Biology}

The flowers were green and chamber-shaped with pink openings. They were grouped in compound racemes on terminal branches (Fig. 2A, B). Staminate flowers possessed ten rimose anthers and a rudimentary pistil while pistillate flowers possessed rudimentary anthers and a punctiform gynoecium with one ovule (Fig. 2C). All morphological parameters analyzed differed between staminate and pistillate flowers (Tab. 2). Staminate flowers were larger than pistillate ones in all size variables analyzed (length, diameter [Tab. 2] and volume [Fig. 3]). Apparently flowers produced nectar, but in very small quantities in the bottom of the flower chamber, which made measurements impractical.

We observed Meliponini bees visiting flowers and collecting pollen from staminate flowers during diurnal observations. During our observations at night we did not record flower visitors. By collecting pollinators from the flower chambers using Ethyl-acetate, we found thrips, small flies and Staphylinidae beetles as the main potential pollinators (Fig. 2E, F). The observation of pistils under fluorescent microscopy showed that only $6.0 \%$ of the analyzed pistils had pollen grains germinating and pollen tubes growing. Pollen grain viability was $98.4 \pm 1.0 \%$, showing no limitation of pollen grain production.

\section{Discussion}

The Neea theifera population showed a balanced sex ratio when considering the entire population or each altitudinal class separately. Theoretically, the sex ratio in dioecious organisms tends to have a dynamic equilibrium around 1:1, because the occurrence of a deviation toward one sex would confer to the opposite sex a lower intragender competition and consequent reproductive advantage (Emlem \& Oring 1977; López \& Dominguez 2003). Studies of dioecious Cerrado species have shown balanced (Lenza \& Oliveira 2005) and biased sex ratios, probably caused by environmental pressures (Amorim \& Oliveira 2006). When considering OSR (ratio between staminate and pistillate flowers), a deviation toward staminate flowers was observed, caused by the larger number of flowers produced by male plants. Male plants producing more flowers per individual is a common feature of dioecious species (Opler \& Bawa 1978; Sutherland 1986; Freeman et al. 1997), including Cerrado plants belonging to different families (Oliveira 1996; Fuzeto et al. 2001; Lenza \& Oliveira 2005; Amorim \& Oliveira 2006). Male individuals allocate resources to produce the largest number of the flowers, since their fitness is directly linked to quantity of released pollen grains (Lloyd \& Webb 1977).

Female plants in dioecious species have higher resource requirements for reproduction than male plants, since female plants bear the fruit production costs (Bierzychudek \& Eckhart 1988; Freeman et al. 1997). The fruit production process is energetically expensive and could be more dramatic in dioecious plants, because many of them, including $N$. theifera, produce bird dispersed, fleshy fruits (Renner \& Ricklefs 1995; Vamosi \& Vamosi 2004). This difference of resource requirement is possibly responsible for the differential sexual maturation observed in the $N$. theifera population, indicated by the smaller (height and basal area) reproductive male plants. The earlier sexual maturation of male plants is also a common trend in dioecious species (e.g. Opler \& Bawa 1978; Amorim \& Oliveira 2006). As female plants require more energy for reproduction (production and maturation of fruits) they need to accumulate more resources, which means being larger before reaching sexual maturity. Spatial segregation according to gender in dioecious plants is more commonly associated with anemophily or sexual lability (Bierzychudek \& Eckhart 1988; Freeman et al. 1997). Vegetative reproduction is also associated to spatial segregation of sexes (Freeman et al. 1997; Amorim \& Oliveira 2006). Neea theifera is pollinated by small insects and since we did not find evidence of sexual lability or vegetative reproduction, the sexual distribution in this species seems to be the result of unbiased seed dispersal and seedling establishment.

Besides sexual differences, plant size was affected by the altitudinal gradient. Individuals from higher altitudes were smaller than individuals from the lower parts of the gradient for both genders. The soil from cerrado rupestre is naturally shallow, and poor in organic matter and nutrients (Ribeiro \& Walter 1998; Mendes-Rodrigues et al. 2010). When it comes to hillside areas, soils from higher 


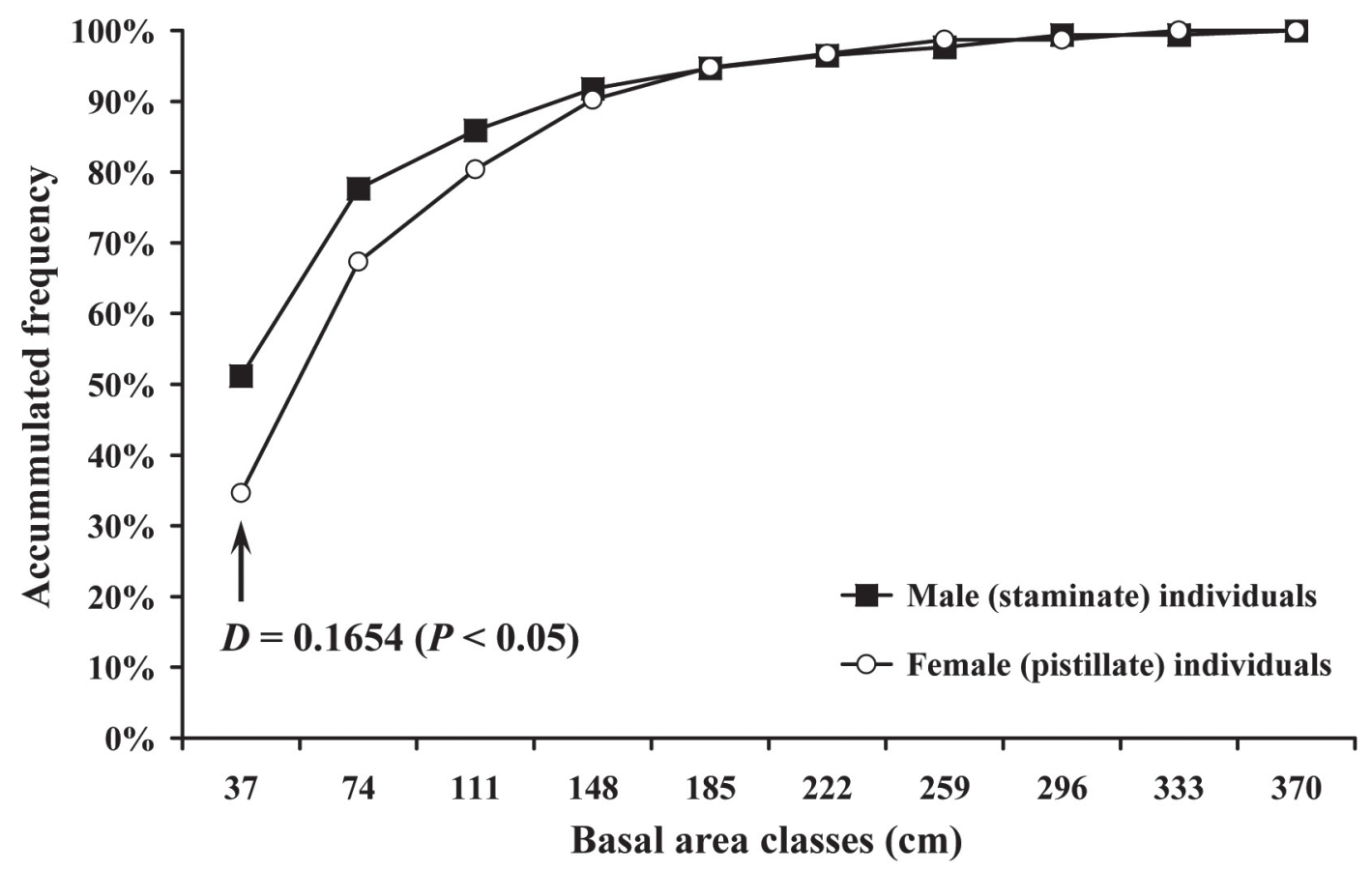

Figure 1. Cumulative frequency distributions of basal area of staminate $(\bullet)$ and pistillate ( $\circ$ ) individuals of the Neea theifera population at PESCAN, Caldas Novas, GO, Brazil. Arrow indicates the greatest difference between sexes by the Kolmogorov-Smirnov $(D)$ analysis.

sites are poorer because of the lixiviation process, which impairs tree growth. In the studied area, $N$. theifera trees were mainly found on these sloped sites, which possibly affected the plant growth pattern along the altitudinal-soil gradient resulting in smaller trees at higher altitudes. In this site, Mendes-Rodrigues et al. (2010) found an increase in soil acidity and aluminum content toward higher altitudes and an inverse trend for some other minerals. It is important to note that in this study the authors evaluated an altitudinal gradient smaller than ours (from 795 to $907 \mathrm{~m}$ a.s.l.), nevertheless, they found a soil quality gradient. Despite this soil gradient and the influence on plant growth, there were no differences in sex ratios along the altitudinal gradient as reported in other studies (Marques et al. 2002; Ortiz et al. 2002).

Dioecious plants often produce small and inconspicuous flowers and are pollinated by small generalist insects (Renner \& Feil 1993; Renner \& Ricklefs 1995; Vamosi et al. 2003; Vamosi \& Vamosi 2004). Additionally, it is common among dioecious groups that male and female individuals present dissimilar investment in reproductive structures (Grant 1995; Freeman et al. 1997). As shown in N. theifera, staminate flowers are more numerous and generally larger making them more conspicuous and attractive to the pollinators (Delph et al. 1996; Humeau et al. 2003; Lenza \& Oliveira 2005; Amorim \& Oliveira 2006). Larger flowers in male plants may be related to the selection pressure toward massive dispersion of pollen in the environment (Bawa \& Opler 1975; Bawa 1980). Intra-sexual selection pressure among male individuals also favors the presence of larger staminate flowers, since it would increase the frequency of flowers visitors (Bawa 1980; Humeau et al. 2003). On the other hand, several studies report that female individuals present more investment in the production of flower resources, such as nectar (Bawa \& Opler 1975; Bawa \& Beach 1981; Amorim \& Oliveira 2006). In the case of N. theifera, both staminate and pistilate flowers produce nectar, but in very small quantities making its flowers less attractive for visitors looking for this floral resource. Pollination by deceit, promoted by visitors exploring for pollen, which occurs in the monoecious genus Begonia (Agren \& Schemsk 1991), could complement the pollination service as some small bees were observed collecting pollen in staminate flowers and then visiting pistillate flowers of $N$. theifera. Differences between sexual morphs in dioecious plants may promote directional pollen flow between staminate and pistillate flowers (Opler \& Bawa 1978; Bawa \& Beach 1981).

Results from fluorescent microscopy showed low pollination efficiency for $N$. theifera. Although we did not quantify fruit set in the studied population, Oliveira (1996) reported a low fruit set in another Cerrado population of $N$. theifera (8\%). The flower visitors encountered characterized this plant as pollinated by very small insects, as around $5 \%$ of the woody flora of the Cerrado (Oliveira \& Gibbs 2000), which is similar to many dioecious species of this biome (Oliveira 1996). Pollination by small generalist insects has been widely associated to the dioecy and $N$. theifera adds another example to this trend. In spite of the low fertilization ratio, it presents 

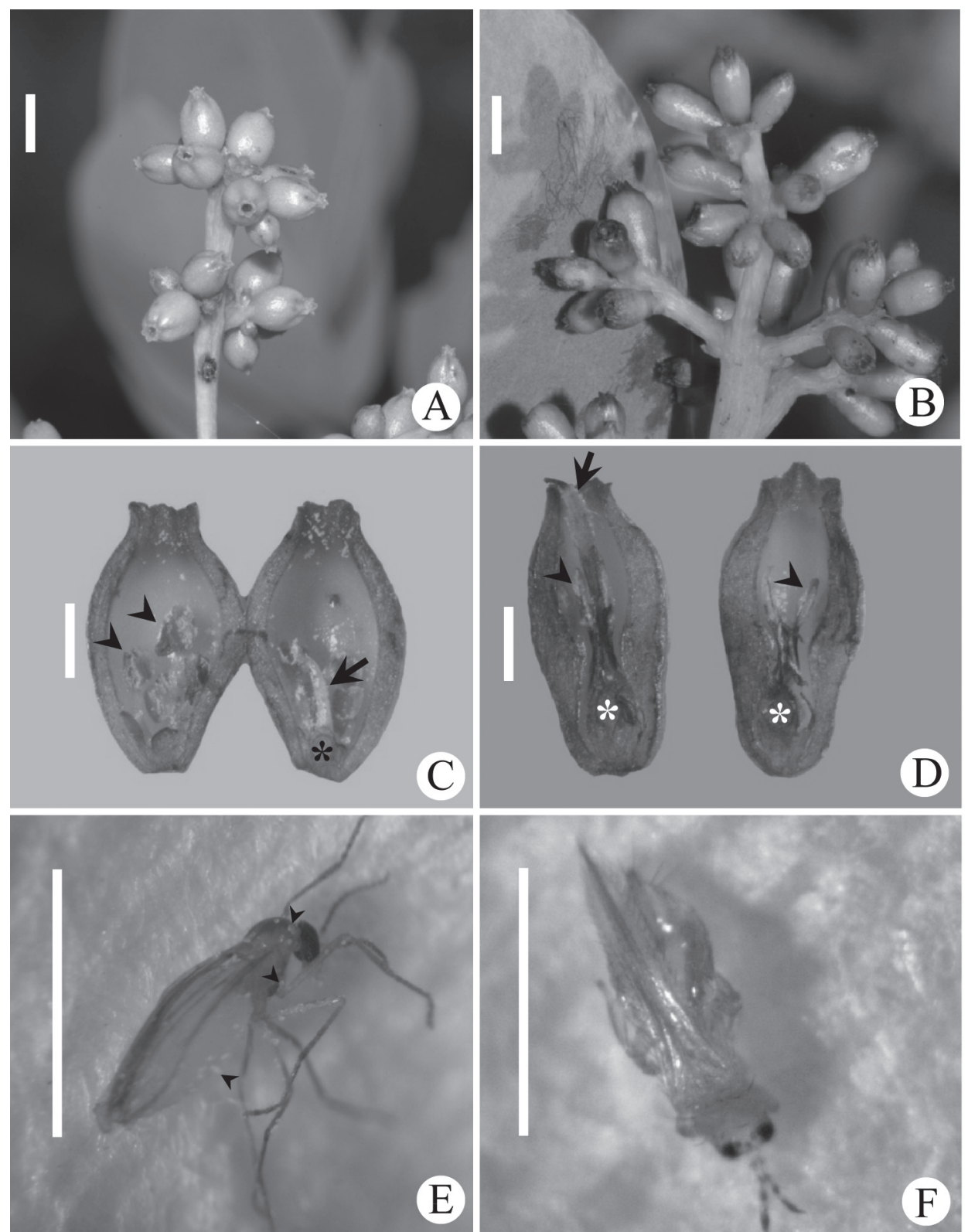

Figure 2. Floral biology of Neea theifera at PESCAN, Caldas Novas, GO, Brazil. A. Staminate inflorescence (bar: 5mm); B Pistillate inflorescence (bar: $5 \mathrm{~mm}$ ); C. Longitudinal section of a staminate flower (bar: $2 \mathrm{~mm}$ ) exposing functional anthers (arrow heads) and the female rudimentary organs: pistil (arrow) and ovule (star); D. Longitudinal section of a pistillate flower (bar: $2 \mathrm{~mm}$ ) exposing female functional organs: style (arrow) and ovary with one ovule (stars) and rudimentary anthers (arrow heads); E. A small Diptera (note the pollen loads: small white dots pointed by arrow heads) (bar: $0.5 \mathrm{~mm}$ ); F. a thrips, commonly recorded in the flower chambers (bar: $0.5 \mathrm{~mm}$ ).

high pollen viability. In this sense, the small number of visitors and possible limitation in pollination service would explain the low reproduction success of the species.

The results presented in this study carried out for a very common woody Cerrado dioecious plant species corroborate many ideas proposed in the past decades as general features for the ecology of dioecious plants. These features include inconspicuous flowers pollinated by small and generalist insects, production of fleshy fruits dispersed by vertebrates and differential resource allocation between genders (indicated by the OSR and earlier sexual maturation of male plants). Our data also suggest that reproduction of $N$. theifera is impaired by pollinator limitation caused by generalist small insects with low a capability of pollen transport between plants of different sexes. Although differential sex ratio was not observed along the altitudinal gradient, it was shown that the altitude in conjunction with soil variation had an influence on the growth pattern of this species and may play an important role in its biology and development. 


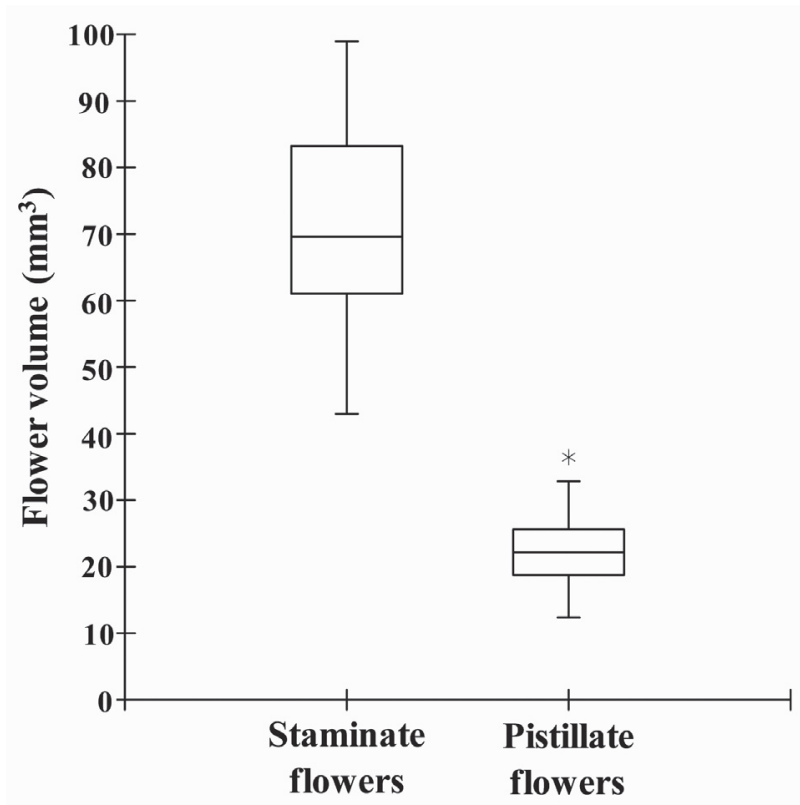

Figure 3. Mean staminate and pistillate flower volume of Neea theifera at PESCAN, Caldas Novas, GO, Brazil. Student t-test showed significant difference between flower morphs $(t=30.66, \mathrm{df}=198, P<0.01)$. Star represents an outlier value.

Table 2. Reproductive variation in male and female individuals of Neea theifera at PESCAN, Caldas Novas, GO, Brazil. Different letters at the same line indicate statistically significant differences between sexes $(P<0.01)$ using Mann-Whitney $(U)$ test or Student's $t$-test.

\begin{tabular}{lllll}
\hline & & \multicolumn{3}{c}{ Mean \pm Standard Deviation } \\
\cline { 3 - 5 } Measured variable & $\mathrm{N}^{*}$ & Male & Female & $t$ or $U$ test \\
\hline Corolla length $(\mathrm{mm})$ & 100 & $6.74 \pm 0.57 \mathrm{a}$ & $4.65 \pm 0.54 \mathrm{~b}$ & $U=9997.0$ \\
Corolla diameter $(\mathrm{mm})$ & 100 & $3.67 \pm 0.32 \mathrm{a}$ & $2.47 \pm 0.21 \mathrm{~b}$ & $t=31.678$ \\
Flower per inflorescence & 20 & $75.10 \pm 28.81 \mathrm{a}$ & $51.19 \pm 14.17 \mathrm{~b}$ & $t=3.412$ \\
Inflorescence per plant & 3 & $46.00 \pm 14.42 \mathrm{a}$ & $39.33 \pm 7.77 \mathrm{a}$ & $t=0.705$ \\
\hline
\end{tabular}

${ }^{*}$ Sample size per flower morph.

\section{Acknowledgements}

We thank the Programa de Pós Graduação em Ecologia e Conservação dos Recursos Naturais of Universidade Federal de Uberlândia and PESCAN administration for logistical support and facilities during the Field Course in Ecology at PESCAN. We are very grateful to the reviewers who provided useful suggestions to improve the manuscript and to Amanda F. Cunha and Mauricio Fernández for comments on an earlier version. We also thank CAPES, CNPq and FAPEMIG for financial support.

\section{References}

Agren, J. \& Schemske, D.W. 1991. Pollination by deceit in a Neotropical monoecious herb, Begonia involucrate. Biotropica 23: 235-241.

Amorim, F.W. \& Oliveira, P.E. 2006. Estrutura sexual e ecologia reprodutiva de Amaioua guianensis Aubl. (Rubiaceae), uma espécie dióica de formações florestais de Cerrado. Revista Brasileira de Botânica 29: 353-362.

Batalha, M.A. \& Mantovani, W. 2000. Reproductive phenological patterns of Cerrado plant species at the Pé-de-Gigante reserve (Santa Rita do Passa Quatro, SP, Brazil): a comparison between the herbaceous and wood floras. Revista Brasileira de Biologia 60: 129-145.

Bawa, K.S. 1980. Evolution of dioecy in flowering plants. Annual Review of Ecology and Systematic 11: 15-39.

Bawa, K. S. \& Beach, J. H. 1981. Evolution of Sexual Systems in Flowering Plants. Annals of the Missouri Botanical Garden 68: 254-274.

Bawa, K.S. \& Opler, P.A. 1975. Dioecism in tropical forest trees. Evolution 29: 167-179.

Bawa, K.S.; Perry, D.R. \& Beach, J.H. 1985. Reproductive biology of tropical lowland rain forest trees. I. Sexual systems and incompatibility mechanisms. American Journal of Botany 72: 331-345.

Bierzychudek, P. \& Eckhart, V. 1988. Spatial segregation of the sexes of dioecious plants. The American Naturalist 132: 34-43.

Borges, N.H. \& Shepherd, J.G. 2005. Flora e estrutura do estrato lenhoso numa comunidade de Cerrado em Santo Antônio do Leverger, MT, Brasil. Revista Brasileira de Botânica 28: 61-74.

Delph, L.F.; Galloway, L.F. \& Stanton, M.L. 1996. Sexual dimorphism in flower size. The American Naturalist 148: 299-320.

Emlen, S.T. \& Oring, L.W. 1977. Ecology, sexual selection, and the evolution of mating systems. Science 197: 215-223.

Freeman, D.C.; Doust, J.L.; El-Keblawi, A.; Miglia, K.J. \& McArthur, E.D. 1997. Sexual specialization and inbreeding avoidance in the evolution of dioecy. Botanical Review 63: 65-92.

Fuzeto, A.P.; Barbosa, A.A.A \& Lomônaco, C. 2001. Cabralea camjerana subdp. polytricha (Adri. Juss) Penn. (Melliaceae), uma espécie dióica. Acta Botanica Brasilica 15: 167-175.

Grant, V. 1995. Sexual selection in plants: pros and cons. Proceedings of the National of Sciences of the United States of America 92: 1247-1250.

Humeau, L.; Pailler, T. \& Thompson, J.D. 2003. Flower size dimorphism in diclinous plants native to La Réunion Island. Plant Systematics and Evolution 240: 163-173.

Köppen, W. 1948. Climatología. Fondo de Cultura Económica, México.

Lenza, E. \& Oliveira, P.E. 2005. Biologia reprodutiva de Tapirira guianensis Aubl. (Anarcadinaceae), uma espécie dióica em mata de galeria do Triangulo Mineiro, Brasil. Revista Brasileira de Botânica 28: 180-190.

Lima, T.A.; Pinto, J.R.R.; Lenza, E. \& Pinto, A.S. 2010. Florística e estrutura da vegetação arbustivo-arbórea em uma área de cerrado rupestre no parque estadual da Serra de Caldas Novas, Goiás. Biota Neotropica 10: 159-166.

Lloyd, D.G. \& Webb, C.J. 1977. Secondary sex characters in plants. Botanical Review 42: 177-216.

Lopes, S.F.; Vale, V.S \& Schiavini, I. 2009. Efeito de queimadas sobre a estrutura e composição da comunidade vegetal lenhosa do cerrado sentido restrito em Caldas Novas, GO. Revista Árvore 33: 695-704.

López, S. \& Domínguez, C.A. 2003. Sex choice in plants: facultative adjustment of the sex ration in the perennial herb Begonia gracilis. Journal of Evolutionary Biology 16: 1177-1185.

Marques, A.R.; Fernandes, G.W.; Reis, I.A. \& Assunção, R.M. 2002. Distribution of adult male and female Baccharis concinna (Asteraceae) in the rupestrian fields of Serra do Cipó, Brazil. Plant Biology 4: 94-103.

Martin, F.W. 1959. Staining and observing pollen tubes in the style by means of fluorescence. Stain Technology 34: 125-128.

Martins, F.Q. \& Batalha, M.A. 2006. Pollination systems and floral traits in Cerrado woody species of the upper Taquari region (Central Brazil). Brazilian Journal of Biology 66: 543-552.

Matallana, G.; Wendt, T.; Araujo, D.S.D. \& Scarano, F. 2005. High abundance of dioecious plants in a tropical coastal vegetation. American Journal of Botany 92: 1513-1519.

Mendes-Rodrigues, C.; Araújo, F.P.; Barbosa-Souza, C.; Barbosa-Souza, V.; Ranal, M.A.; Santana, D.G. \& Oliveira, P.E. 2010. Multiple dormancy and maternal effect on Miconia ferruginata (Melastomataceae) seed germination, Serra de Caldas Novas, Goiás, Brazil. Revista Brasileira de Botânica 33: 92-105.

Mitchell, C. \& Diggle, P. 2005. The evolution of unisexual flowers: morphological and functional convergence results form diverse developmental transitions. American Journal of Botany 92: 1068-1076. 
Oliveira, P.E. 1996. Dioecy in the Cerrado vegetation of Central Brazil. Flora 191: 235-243.

Oliveira, P.E. \& Gibbs, P.E. 2000. Reproductive biology of wood plants in a Cerrado community of central Brazil. Flora 195: 311-329.

Opler, P.A. \& Bawa, K.S. 1978. Sex ratios in tropical forest trees. Evolution 32: 812-821.

Ortiz, P.L.; Arista, M. \& Talavera, S. 2002. Sex ratio and reproductive effort in the dioecious Juniperus communis subsp. alpina (Suter) Celak. (Cupressaceae) along an altitudinal gradient. Annals of Botany 89: 205-211.

Renner, S.S. \& Feil, J.P. 1993. Pollinators of tropical dioecious angiosperms. American Journal of Botany 81: 1100-1107.

Renner, S.S. \& Ricklefs, R.E. 1995. Dioecy and its correlates in the flowering plants. American Journal of Botany 82: 596-606.

Ribeiro, J.F. \& Walter, B.M. 1998. Fitofisionomias do bioma Cerrado. Pp. 89-152. In: Sano, S.M. \& Almeida, S.P. (Eds). Cerrado: Ambiente Flora. Brasília, EMBRAPA.

Santos, M.L. 2003. Florística e biologia reprodutiva de espécies de Melastomataceae do Parque Estadual da Serra de Caldas Novas e Parque Estadual dos Pirineus, Goiás. Doctoral Thesis. Universidade de Brasília, Brasília.

Silva Jr, M.C. 2005. Guia de campo: 100 árvores do Cerrado. Brasília, Rede de Sementes do Cerrado.
Silva, L.O.; Costa, D.A.; Espírito-Santo-Filho, K.; Ferreira, H.D. \& Brandão D. 2002. Levantamento florístico e fitossociológico em duas áreas de cerrado sensu stricto no Parque Estadual da Serra de Caldas Novas, Goiás. Acta Botanica Brasilica 16: 43-53.

Sobrevilla, C. \& Arroyo, M.T.K. 1982. Breeding systems in a Montane Tropical Cloud Forest in Venezuela. Plant Systematics and Evolution 140: 19-37.

Sokal, R.R. \& Rohlf, F.J. 1981. Biometry. New York, W. H. Freeman and Company.

Sutherland, S. 1986. Floral sex rations, fruit-set, and resource allocation in plants. Ecology 67: 991-1001.

Thomson, J.D. \& Barret, S. 1981. Selection for outcrossing, sexual selection, and evolution of dioecy in plants. The American Naturalist 118: $443-449$.

Vamosi, J.C. \& Vamosi, S.M. 2004. The role of diversification in causing the correlations of dioecy. Evolution 58: 723-731.

Vamosi, J.C.; Otto, P.S. \& Barret, C.H. 2003. Phylogenetic analysis of the ecological correlates of dioecy in angiosperms. Journal of Evolution Biology 16: 1006-1018.

Zar, J.H. 1999. Biostatistical Analysis. 4 ed. Upper Saddle River, Prentice Hall. 